\section{Rooting and Acclimatization of In Vitro-grown Shoots from Mature Trees of Three Persian Walnut Cultivars}

\author{
Kourosh Vahdati ${ }^{1}$, Charles Leslie, Zabihollah Zamani ${ }^{1}$, and \\ Gale McGranahan ${ }^{2}$ \\ Department of Pomology, University of California, Davis, CA 95616
}

Additional index words. Juglans regia, micropropagation, tissue culture

\begin{abstract}
In vitro rooting of three commercial cultivars of Persian walnut (Juglans regia L.), 'Sunland', 'Chandler', and 'Vina', was examined using a two-phase rooting procedure: root induction in the dark on Murashige and Skoog (MS) medium with $15 \mu \mathrm{M} \mathrm{IBA}$ followed by root development in the light on a mixture of one-quarter strength Driver Kuniyuki Walnut (DKW) basal medium and vermiculite $(1: 1.25$, v/v). Rooting percentages were: 'Sunland' (94\%), 'Chandler (55\%), and 'Vina' (27\%). A positive relationship was observed between the vigor of cultivars and rooting ability, but shoot length did not affect rooting success. Rooting was optimum when shoots were cultured on root induction media for 6 to 8 days. Increasing the sucrose level in the root induction medium to $40 \mathrm{~g} \cdot \mathrm{L}^{-1}$ improved rooting, and shoots induced to root at $22^{\circ} \mathrm{C}$ rooted more readily than those induced at $30^{\circ} \mathrm{C}$. Either increasing or decreasing the nitrogen level in the multiplication medium had a negative effect on rooting. Rooted walnut shoots often cease growth during acclimatization, resulting in shoot rosetting. Spray application of Promalin ${ }^{\circledR}(25$ $\mathrm{mL} \cdot \mathrm{L}^{-1}$ ) caused buds to break and induced elongation of shoots. Chemical name used: indole-3-butyric acid (IBA).
\end{abstract}

Persian walnut is a difficult-to-root species. Rooting and acclimatization are the main factors limiting micropropagation (Chenevard et al., 1995; Ripetti et al., 1994; Saadat and Hennerty, 2001). In the last decade, walnut tree improvement programs have released promising new cultivars, but problems in rooting microshoots or conventional cuttings limit the development of new rootstocks and production of cultivars on their own roots (Navatel and Bourrain, 2001; Scaltsoyiannes et al., 1997).

Production of Persian walnut cultivars on theirown roots has several potential advantages over propagation by grafting. Grafting is an expensive and time-consuming practice. Ownrooted plants provide a means of establishing genetically uniform orchards, without the risk of blackline disease caused by cherry leafroll virus in trees grafted to black or hybrid walnut rootstocks (Mircetich and Rowhani, 1984). A method of rooting microshoots or conventional cuttings is also required to enable production of selected disease-resistant rootstocks and transgenic plants.

Received for publication 28 Oct. 2002. Accepted for publication 15 May 2003. We thank Mitch Watnik of the Statistics Lab, Univ. of California-Davis, for advising and reviewing the analysis, and we thank the Ministry of Science, Research, and Technology of Iran, the Univ. of Tehran, and the Walnut Marketing Board of the United States for supporting the stay of Kourosh Vahdati in the United States.

${ }^{1}$ Present address: Dept. of Horticultural Sciences, Faculty of Agriculture, Univ. of Tehran, Karaj, Iran.

${ }^{2}$ To whom reprint requests should be addressed. E-mail address: ghmcgranahan@ucdavis.edu
Mature clones on their own roots may be more precocious and productive than grafted trees (Lopez, 2001; McGranahan et al., 1988). A recent comparison of 'Chandler' grafted on 'Paradox' hybrid (J.hindsii XJ.regia) seedling rootstock to micropropagated, own-rooted 'Chandler' showed that 'Chandler' trees on their own roots exhibited superior vigor and yield (Hasey et al., 2001). Preliminary field observations (unpublished data) also suggested catkin production may be delayed or reduced on own-rooted trees, an alteration that could reduce pistillate flower abscission losses in susceptible cultivars such as 'Serr' (McGranahan et al., 1994). These factors have increased interest in the production of walnut cultivars on their own roots.

Rooting of micropropagated walnuts has been pursued since 1984, when Driver Kuniyuki Walnut (DKW) medium was introduced specifically for multiplying this plant (Driver and Kuniyuki, 1984). Driver and Kuniyuki (1984) proposed an ex vitro rooting method for 'Paradox' hybrid walnut based on a 5-mm IBA quick dip, followed by transfer to a sand : peat: perlite mixture for root emergence. Driver and Suttle (1987) introduced a patented method for direct field rooting of in vitro-derived microshoots grown on a modified DKW medium (McGranahan et al., 1987) under decreased light and temperature. Microshoots were then washed in a slurry of systemic fungicides, and the basal ends were dipped in a rooting powder composed of $2 \mathrm{~g} \mathrm{~K}$-IBA in $100 \mathrm{~g}$ talc. Treated shoots were planted directly into outdoor nursery beds and covered with a set of Styrofoam and transparent plastic cups to maintain high humidity, regulate light intensity, and insulate them from excessive heat. Although this method was successful experimentally, it was not sufficiently reliable or efficient for commercial application.

Jay-Allemand et al. (1992) developed a two-phase in vitro rooting protocol that used vermiculite to increase aeration during the second (root development) phase. This protocol facilitated improved rooting and acclimatization of mature Persian walnut cultivars by reducing the variation in rooting success seen on conventional, gelled media and improving survival during acclimatization (Ripetti et al., 1994).

Navatel and Bourrain (2001) used a modification of this two-phase rooting protocol to root and acclimatize three vigorous seedling rootstocks of J. regia and three cultivars ('Lara', 'Chandler', and 'Franquette'). Genotypes varied in rooting ability. Saadat and Hennerty (2001) also examined several variations of this two-step procedure and obtained the best rooting by culturing microshoots on half-strength DKW medium supplemented with $20 \mu \mathrm{M}$ IBA for $9 \mathrm{~d}$ in the dark, followed by transfer to Jiffy-7 pots.

In spite of this progress, existing procedures need improvement to allow efficient plant production for research and for commercialization. To date, only one company, located in Spain, has implemented commercial production on a major scale (Lopez, 2001). Rootability of genotypes varies widely, and further refinements are needed to enable routine production of the more difficult-to-root genotypes (Vahdati et al., 2001). The objectives of this study were to: further optimize the two-step rooting procedure and acclimatization methods for three commercial cultivars of Persian walnut ('Sunland', 'Chandler', and 'Vina'); characterize variation in the rooting ability of these cultivars; and elucidate physiological barriers to rooting success in Persian walnut.

\section{Materials and Methods}

Plant material and culture conditions. Microshoots of three commercial cultivars of Persian walnut, 'Sunland', 'Chandler', and 'Vina', were multiplied on a medium containing DKW salts supplemented with $2.1 \mathrm{~g} \cdot \mathrm{L}^{-1}$ Phytagel (Sigma Chemical Co., St. Louis), 30 $\mathrm{g} \cdot \mathrm{L}^{-1}$ sucrose, $4.4 \mu \mathrm{M}$ 6-benzyladenine (BA), and $0.05 \mu \mathrm{M}$ IBA (McGranahan et al., 1987). The $\mathrm{pH}$ of the medium was adjusted to 5.5 before adding the Phytagel and autoclaving. Micropropagated shoots were maintained in GA-7 vessels (Magenta Corp., Chicago), four shoots per vessel, at room temperature $\left(25\right.$ to $30{ }^{\circ} \mathrm{C}$ ) under a 16 -h photoperiod, and transferred biweekly. Light was provided by cool-white fluorescent bulbs located $20 \mathrm{~cm}$ above the containers. Light intensity at the top of containers was $40-60 \mu \mathrm{mol} \cdot \mathrm{m}^{-2} \cdot \mathrm{s}^{-1}$.

For root induction, shoots 3 to $4 \mathrm{~cm}$ long with fresh cuts at the basal end (to remove any callus) were placed on root induction medium in the dark at $22{ }^{\circ} \mathrm{C}$ for $7 \mathrm{~d}$. The induction medium consisted of full-strength MS salts and vitamins (Murashige and Skoog, 1962) 
supplemented with $15 \mu \mathrm{M}$ IBA, $30 \mathrm{~g} \cdot \mathrm{L}^{-1}$ sucrose, and $9 \mathrm{~g} \cdot \mathrm{L}^{-1}$ Kobe agar (Serva Co.). Use of agar and MS basal salts medium instead of quarter-strength DKW during the root induction phase was based on the results reported by Navatel and Bourrain (2001) and Ripetti et al. (1994). The $\mathrm{pH}$ was adjusted to 5.5 before addition of agar and autoclaving.

Following the root induction phase, shoots were transferred to a root development medium consisting of a mix of $1: 1.25(\mathrm{v} / \mathrm{v})$ quarterstrength DKW : vermiculite and maintained in the same environment as for multiplication (Jay-Allemand et al., 1992). To make this medium, $100 \mathrm{~mL}$ of quarter-strength DKW basal medium containing $2.4 \mathrm{~g} \cdot \mathrm{L}^{-1}$ Phytagel and 30 $\mathrm{g} \cdot \mathrm{L}^{-1}$ sucrose was added to $125 \mathrm{~mL}$ nonsifted, coarse, no. 2 grade vermiculite (Therm-O-Rock West, Chandler, Ariz.) in glass Mason canning jars (1-L) and autoclaved. After autoclaving, mouths of the jars were covered with sterile plastic petri dishes to allow light penetration and sealed with parafilm. Eight shoots were placed in each jar for root development, and rooting was evaluated after $28 \mathrm{~d}$. These standard procedures were used for all the rooting experiments unless otherwise stated. Shoots in each experiment were from the same subculture cycle.

Rooting experiments. The two-phase rooting procedure described above was used to compare in vitro rooting of 'Sunland', 'Chandler', and 'Vina'. Following this trial, experiments were conducted to determine factors limiting the rooting of these cultivars. The optimum length of time for the root induction phase was investigated with 'Chandler' by placing shoots on the root induction medium for $2,4,6,8$, or $10 \mathrm{~d}$ before transfer to development medium. Microshoots of 'Vina', the most difficult to root of the cultivars, were used to investigate the effect of shoot length on rooting. After basal trimming, shoots were divided into three length classes $(1.8-2.5,3-4.5$, and $5-6.5 \mathrm{~cm}$ ) for the induction phase. To evaluate the effect of sucrose concentration in the root induction medium, five concentrations (10, $20,30,40$, or $60 \mathrm{~g} \cdot \mathrm{L}^{-1}$ ) were compared using microcuttings of 'Chandler'. The effect of two different induction temperatures, 22 and 30 ${ }^{\circ} \mathrm{C}$, on rooting was compared using the standard induction method on shoots of all three cultivars. Finally, to study the influence of the nitrogen concentration in the multiplication medium on rooting, micropropagated shoots of 'Chandler' were transferred to standard DKW multiplication medium $\left(1416 \mathrm{mg} \cdot \mathrm{L}^{-1}\right.$ $\mathrm{NH}_{4} \mathrm{NO}_{3}$ ), DKW with a doubled concentration of $\mathrm{NH}_{4} \mathrm{NO}_{3}\left(2932 \mathrm{mg} \cdot \mathrm{L}^{-1}\right)$, DKW with half the normal $\mathrm{NH}_{4} \mathrm{NO}_{3}\left(708 \mathrm{mg} \cdot \mathrm{L}^{-1}\right)$, or DKW without $\mathrm{NH}_{4} \mathrm{NO}_{3}$. After $21 \mathrm{~d}$ of culture on these four media, shoots were used for rooting using the standard procedure described above.

All experiments on in vitro shoots were conducted once and separately due to the limited availability at any given time of sufficient shoot numbers for a multifactor experiment. A completely randomized design, with at least three jars of eight shoots each, was used for each experiment. The data were transformed as necessary and were analyzed using analy-

Table 1. Rooting of in vitro shoots of three Persian walnut cultivars induced to root on MS medium with $15 \mu \mathrm{M}$ IBA in the dark for 1 week, and then transferred to root development medium in the light for $28 \mathrm{~d}$.

\begin{tabular}{lcccccc}
\hline Cultivar & $\begin{array}{c}\text { Treated } \\
(\text { no. })\end{array}$ & $\begin{array}{c}\text { Rooted } \\
(\%)\end{array}$ & $\begin{array}{c}\text { Roots : shoot } \\
(\text { no. })\end{array}$ & $\begin{array}{c}\text { Root } \\
\text { length }(\mathrm{cm})\end{array}$ & $\begin{array}{c}\text { Longest } \\
\text { root }(\mathrm{cm})\end{array}$ & $\begin{array}{c}\text { Root } \\
\text { diam }(\mathrm{mm})\end{array}$ \\
\hline Sunland & 88 & $94 \% \mathrm{a}^{\mathrm{z}}$ & $4.4 \pm 0.27 \mathrm{a}^{\mathrm{y}}$ & $1.9 \pm 0.12^{\mathrm{Ns}}$ & $2.6 \pm 0.15^{\mathrm{Ns}}$ & $1.8 \pm 0.06 \mathrm{a}$ \\
Chandler & 76 & $55 \% \mathrm{~b}$ & $2.7 \pm 0.30 \mathrm{ab}$ & $1.9 \pm 0.23^{\mathrm{Ns}}$ & $2.5 \pm 0.21^{\mathrm{Ns}}$ & $1.4 \pm 0.09 \mathrm{ab}$ \\
Vina & 67 & $27 \% \mathrm{c}$ & $1.4 \pm 0.17 \mathrm{~b}$ & $1.6 \pm 0.31^{\mathrm{Ns}}$ & $1.8 \pm 0.31^{\mathrm{Ns}}$ & $0.9 \pm 0.12 \mathrm{~b}$ \\
\hline
\end{tabular}

${ }^{2}$ Means in each column followed by the same letter are not significantly different according to Tukey-Kramer multiple comparisons test $(\alpha \leq 0.05)$.

${ }^{y}$ Mean \pm SE.

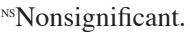
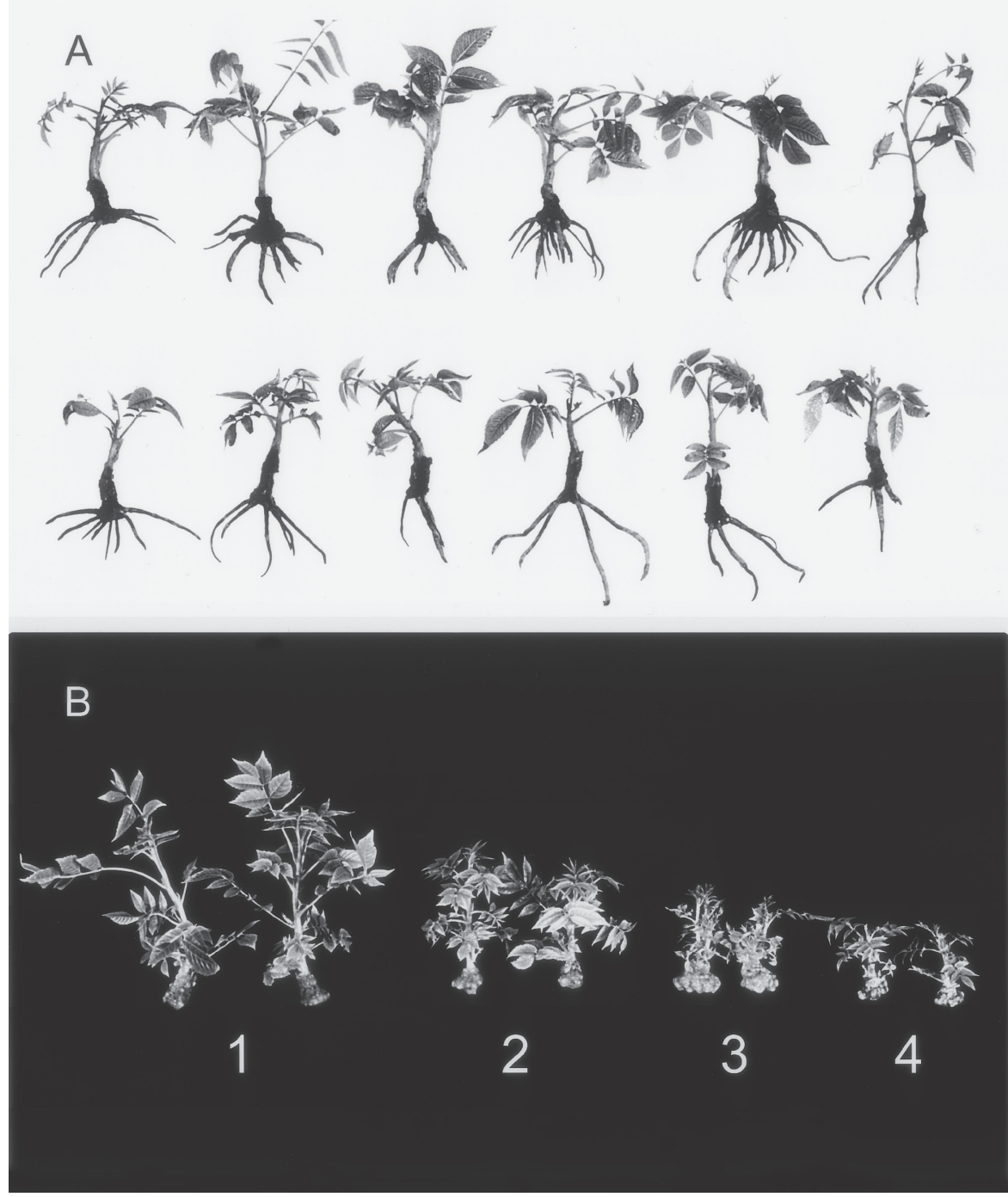

Fig. 1. Walnut shoots. (top) Rooted 'Sunland' walnut microshoots after 4 weeks on root development medium. Roots were induced by application of $15 \mu \mathrm{M}$ IBA in MS for 1 week at $22^{\circ} \mathrm{C}$ in the dark. (bottom) 'Chandler' microshoots after 3 weeks on multiplication medium containing different concentrations of $\mathrm{NH}_{4} \mathrm{NO}_{3}$ : 1) DKW with doubled $\mathrm{NH}_{4} \mathrm{NO}_{3}\left(2932 \mathrm{mg} \cdot \mathrm{L}^{-1}\right)$; 2) standard concentration $\left(1416 \mathrm{mg} \cdot \mathrm{L}^{-1}\right.$ $\left.\mathrm{NH}_{4} \mathrm{NO}_{3}\right) ; 3$ ) half $\mathrm{NH}_{4} \mathrm{NO}_{3}\left(708 \mathrm{mg} \cdot \mathrm{L}^{-1}\right)$; and 4) without $\mathrm{NH}_{4} \mathrm{NO}_{3}\left(0 \mathrm{mg} \cdot \mathrm{L}^{-1}\right)$.

sis of variance (ANOVA), followed by the Tukey-Kramer multiple comparisons test (SAS/STAT User's Guide, version 6, 4th ed., Cary, N.C.).

Acclimatization. After $28 \mathrm{~d}$ in root development medium, rooted shoots were washed thoroughly to remove residual medium. Rooted plantlets were potted into a mixture of 3 fir bark : 1 peat : 1 volcanic rock $(\mathrm{v} / \mathrm{v})$ and $2.15 \mathrm{~kg} \cdot \mathrm{m}^{-3}$ oyster lime. Plants were placed under a plastic tent on a bench in a fan and pad greenhouse, where high humidity was maintained using a humidifier. During a $14-$ to $21-\mathrm{d}$ period, pots in the tent were moved progressively farther from the humidifier to reduce their ambient humidity. The temperature in the tent was $\approx 22{ }^{\circ} \mathrm{C}$ and plants were not fertilized during acclimatization.

During acclimatization, growth of walnut plantlets is easily arrested by any stress (Navatel and Bourrain, 2001), and plants tend to rosette in the greenhouse following acclimatization. Therefore, the effects of Promalin ${ }^{\circledR}$ (Valent Biosciences, Libertyville, Ill.) and gibberellic acid $\left(\mathrm{GA}_{3}\right)$ on budbreak and stem elongation were examined. According to the 
label, Promalin contains $1.8 \%$ (w:w) $\mathrm{GA}_{4 / 7}$ and $1.8 \%(\mathrm{w}: \mathrm{w})$ BAP. The water control and treatments $\left(12.5\right.$ or $25 \mathrm{~mL} \cdot \mathrm{L}^{-1}$ Promalin or 25 $\mathrm{mg} \cdot \mathrm{L}^{-1} \mathrm{GA}_{3}$ ) were applied by spraying foliage and apical buds to runoff. Each treatment included 11 rooted plants. Shoot growth and number of new leaves were measured $28 \mathrm{~d}$ after treatment application.

\section{Results and Discussion}

Cultivars. There were significant differences in the rootability of walnut cultivars (Table 1). Microshoots of 'Sunland', a very vigorous and upright cultivar in the orchard, were the easiest to root (94\%) (Fig. 1). 'Chandler' exhibited intermediate rootability (55\%), and 'Vina' was the most difficult to root $(27 \%)$. 'Chandler' and 'Vina' are less vigorous in the orchard than 'Sunland'(Hendricks etal., 1998). Navatel and Bourrain (2001) also reported an apparent correlation of rhizogenesis with vigor. Number of roots per shoot and root diameter followed a similar pattern, with significant differences apparent between 'Sunland' and 'Vina'. 'Chandler' was intermediate in number and diameter of roots. There were no significant differences among the three cultivars in root length.

Length of induction period. Induction for 6 to $8 \mathrm{~d}$ resulted in more roots per shoot than other treatments (Fig. 2). The rooting percentage differences were nonsignificant and root length was not affected by the duration of induction period. This is consistent with Bourrain and Navatel (1994), who found $6 \mathrm{~d}$ was optimum for root induction; Scaltsoyiannes et al. (1997), who found $6 \mathrm{~d}$ of induction was superior to $3 \mathrm{~d}$; and Navatel and Bourrain (2001), who obtained the best results following $8 \mathrm{~d}$ of induction.

Shoot size. Shoots of three length classes of 'Vina' did not differ in rooting percentage, number of roots per shoot, or root diameter (Table 2). While these data suggest an advantage to rooting small microshoots for plant production because they can be produced more rapidly and in greater numbers, greenhouse observation suggests better survival and acclimatization of the longer shoots, which have greater carbohydrate reserves to sustain root growth (Chenevard et al., 1995) and a more lignified stem capable of warding off soilborne pathogens.

Nitrogen. The growth of microshoots improved with increasing concentrations of ammonium nitrate in the multiplication medium (Fig. 1), but elevated nitrogen during the multiplication stage negatively affected rooting of the derived shoots. Rooting occurred with doubled $\mathrm{NH}_{4} \mathrm{NO}_{3}$ at $24 \%$; standard concentration at $43 \%$, and half-concentration at $14 \%$. Eliminating $\mathrm{NH}_{4} \mathrm{NO}_{3}$ from the multiplication medium stunted the growth of the microshoots so that they could not be used for rooting experiments. The treatments did not affect root number, root length, or apparent root quality (data not shown). Zamani and Vahdati (2001) found that doubling the ammonium nitrate in DKW significantly increased the growth of shoots, and our data agree; however, we found

No. Roots $\longrightarrow$ Rooting \%

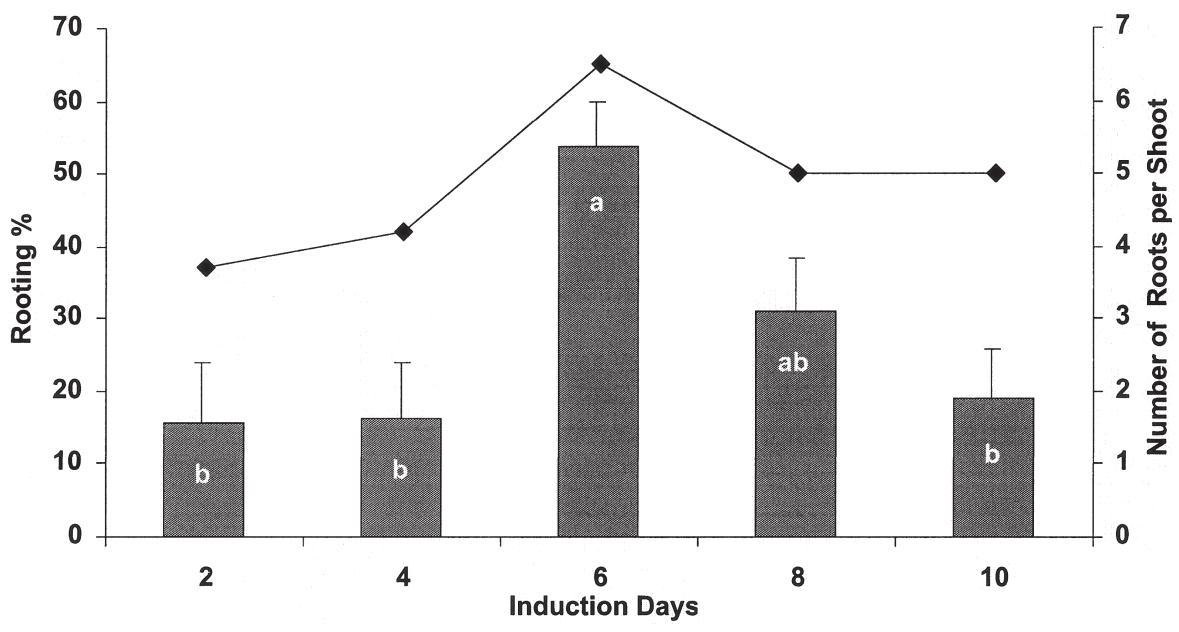

Fig. 2. Effect of the duration of the root induction phase on the number of roots per shoot and rooting percentage of 'Chandler' microshoots. Data for number of roots followed by the same letter are not significantly different according to Tukey-Kramer multiple comparison test at $\alpha \leq 0.05$. Bars represent standard errors of means. Rooting percentages were not statistically different among treatments.

Table 2. Rooting response of three shoot length classes of 'Vina' walnut microshoots induced to root on MS medium with $15 \mu \mathrm{m}$ IBA in the dark for 1 week, and then transferred to root development medium in the light for $28 \mathrm{~d}$.

\begin{tabular}{lccccc}
\hline $\begin{array}{l}\text { Shoot class } \\
(\mathrm{cm})\end{array}$ & $\begin{array}{c}\text { Mean } \\
\text { length }(\mathrm{cm})\end{array}$ & $\begin{array}{c}\text { Treated } \\
(\text { no. })\end{array}$ & $\begin{array}{c}\text { Rooted } \\
(\%)\end{array}$ & $\begin{array}{c}\text { Roots : shoot } \\
(\text { no. })\end{array}$ & $\begin{array}{c}\text { Root } \\
\text { diam }(\mathrm{mm})\end{array}$ \\
\hline Short $(1.8-2.5)$ & $2.2 \pm 0.3 \mathrm{c}^{2}$ & 48 & $23^{\text {Ns }}$ & $2.5 \pm 0.3^{\text {Ns }}$ & $1.2 \pm 0.4^{\text {Ns }}$ \\
Medium $(3-4.5)$ & $3.7 \pm 0.4 \mathrm{~b}$ & 53 & $38^{\text {Ns }}$ & $2.6 \pm 0.6^{\text {Ns }}$ & $1.6 \pm 0.6^{\text {Ns }}$ \\
Tall $(5-6.5)$ & $5.8 \pm 0.5 \mathrm{a}$ & 24 & $38^{\text {Ns }}$ & $1.9 \pm 0.4^{\text {Ns }}$ & $1.4 \pm 0.7^{\text {Ns }}$ \\
\hline
\end{tabular}

${ }^{\mathrm{z}}$ Mean \pm SE. Means in each column followed by the same letter are not significantly different according to Tukey-Kramer multiple comparisons test $(\alpha \leq 0.05)$.

${ }^{\mathrm{s}}$ Nonsignificant.

Table 3. The effect of induction temperature on rooting of three $J$. regia cultivars. Microshoots were induced to root on MS medium with $15 \mu \mathrm{M}$ IBA in the dark for 1 week at two temperatures $\left(22\right.$ and $\left.30^{\circ} \mathrm{C}\right)$, then transferred to root development medium in the light for $28 \mathrm{~d}$.

\begin{tabular}{lcccc}
\hline Cultivar & $\begin{array}{c}\text { Temp } \\
\left({ }^{\circ} \mathrm{C}\right)\end{array}$ & $\begin{array}{c}\text { Treated } \\
(\text { no. })\end{array}$ & $\begin{array}{c}\text { Rooted } \\
(\%)\end{array}$ & $\begin{array}{c}\text { Roots : shoot } \\
(\text { no. })\end{array}$ \\
\hline Sunland & 22 & 71 & 94 & $4.9 \mathrm{a}^{\mathrm{z}}$ \\
& 30 & 12 & 50 & $3.3 \mathrm{~b}$ \\
Chandler & 22 & 31 & 42 & $2.0 \mathrm{a}$ \\
& 30 & 31 & 13 & $1.3 \mathrm{~b}$ \\
Vina & 22 & 32 & 25 & $1.8 \mathrm{a}$ \\
& 30 & 32 & 3 & $1.0 \mathrm{~b}$ \\
\hline
\end{tabular}

${ }^{\mathrm{z}}$ Means in each column followed by the same letter are not significantly different according to Tukey-Kramer multiple comparison test $(\alpha \leq 0.05)$

that multiplying shoots on media with doubled $\mathrm{NH}_{4} \mathrm{NO}_{3}$ reduced their rootability.

Sucrose. Sucrose concentration in the root induction medium significantly affected rooting percentage. Few shoots rooted after treatment on induction medium containing 10 ( $0 \%$ rooting) or $20 \mathrm{~g} \cdot \mathrm{L}^{-1}$ sucrose $(3 \%)$. Rooting percentage increased significantly when the medium contained $30 \mathrm{~g} \cdot \mathrm{L}^{-1}(31 \%)$ and was optimum at $40(62 \%)$ to $60 \mathrm{~g} \cdot \mathrm{L}^{-1}(50 \%)$. Sucrose concentration did not influence quantity or quality of roots. Improved rooting of walnut microshoots induced on higher sucrose concentrations is consistent with observations of Chenevard et al. (1995) and Driver and Suttle (1987). The positive effect of higher sucrose may be the result of an elevated $\mathrm{C}: \mathrm{N}$ ratio.
Table 4. Shoot length $(\mathrm{cm})$ and number of leaves of acclimatized plants of Persian walnut 'Sunland' sprayed with water (control), Promalin (12.5 $\left.\mathrm{mL} \cdot \mathrm{L}^{-1}\right)$, Promalin $\left(25 \mathrm{~mL} \cdot \mathrm{L}^{-1}\right)$ and $\mathrm{GA}_{3}(25$ $\left.\mathrm{mg} \cdot \mathrm{L}^{-1}\right)(\mathrm{n}=11$ plants/treatment $)$. Data were taken 1 month after transfer from fog tent to greenhouse conditions.

\begin{tabular}{lll}
\hline Treatments & $\begin{array}{l}\text { Shoot } \\
\text { length }\end{array}$ & $\begin{array}{c}\text { No. } \\
\text { leaves }\end{array}$ \\
\hline Promalin & $6.19 \mathrm{a}$ & $7.22 \mathrm{a}$ \\
Promalin & $4.13 \mathrm{~b}$ & $6.09 \mathrm{ab}$ \\
$\mathrm{GA}_{3}$ & $3.19 \mathrm{~b}$ & $6.44 \mathrm{ab}$ \\
Water & $1.63 \mathrm{c}$ & $5.09 \mathrm{~b}$ \\
\hline
\end{tabular}

${ }^{2}$ Means followed by the same letter are not significantly different according to Tukey-Kramer multiple comparison test $(\alpha \leq 0.01)$. 
Increased $\mathrm{NH}_{4} \mathrm{NO}_{3}$ improves multiplication but reduces this ratio. Therefore, multiplication on elevated $\mathrm{NH}_{4} \mathrm{NO}_{3}$ concentrations for rapid shoot production may need a simultaneously increased sucrose concentration to maintain this ratio for rooting. Coordinated elevation of both components may enhance production of rooted shoots.

Temperature. Microshoots of all three tested cultivars rooted more effectively when induced at $22{ }^{\circ} \mathrm{C}$ than at $30{ }^{\circ} \mathrm{C}$ (Table 3). 'Sunland' rooted better than 'Chandler' and 'Vina' regardless of temperature. Rooting percentages and the number of roots per shoot were both greater in all cases at the lower temperature. Adventitious root formation in plants often increases with elevated temperatures (Pierik, 1997). McKenna (1997) and Hackett et al. (2000) found higher temperature $\left(30^{\circ} \mathrm{C}\right) \mathrm{im}$ proved rooting of conventional walnut cuttings. Bourrain and Navatel (1994) found that higher temperatures (26 to $28{ }^{\circ} \mathrm{C}$ ) improved shoot quality during multiplication. Driver and Suttle (1987) reduced the temperature from $\approx 25$ to 19 ${ }^{\circ} \mathrm{C}$ during a pre-induction stage, but no studies of the effect of temperature on in vitro walnut root induction have been reported previously. Contrary to our expectations, we found that a lower temperature $\left(22\right.$ vs. $\left.30{ }^{\circ} \mathrm{C}\right)$ during the root induction phase enhanced root initiation and elongation consistently in all three cultivars studied. Perhaps $30^{\circ} \mathrm{C}$ was too high, exceeding the optimum rooting temperature.

Acclimatization. Walnut microshoot sensitivity to stress during acclimatization frequently results in arrest of the apical meristem. Both Promalin and $\mathrm{GA}_{3}$ treatments improved the apical budbreak and shoot elongation of acclimatized greenhouse plants. Shoot length and the number of new leaves emerging were both greatest following application of 25 $\mathrm{mL} \cdot \mathrm{L}^{-1}$ Promalin (Table 4 ). The effect was a result of the elongation of the internodes of the developing shoots. Application of $12.5 \mathrm{~mL} \cdot \mathrm{L}^{-1}$ Promalin or $25 \mathrm{mg} \cdot \mathrm{L}^{-1} \mathrm{GA}_{3}$ also increased shoot length, but to a lesser degree. Control plants sprayed only with water remained rosetted and did not elongate. Bourrain and Navatel (1995) found that both Promalin $\left(25 \mathrm{~mL} \cdot \mathrm{L}^{-1}\right)$ and Dormex $\left(25 \mathrm{~mL} \cdot \mathrm{L}^{-1}\right)$ induced budbreak during acclimatization when applied to walnut plants with arrested growth, but $\mathrm{GA}_{3}$ (Berelex) did not. We found that $\mathrm{GA}_{3}$ did promote some apical bud growth, suggesting GA is active in this process. Further work is needed to characterize the differences between $\mathrm{GA}_{3}$ and $\mathrm{GA}_{4 / 7}$, determine the optimum GAconcentration, and determine the role of cytokinin in this effect.

In summary, micropropagation of mature trees of Persian walnut was feasible, but factors reducing rooting in some cultivars, such as 'Vina', remain to be determined. Rootability appeared to correspond with field vigor. Shoot size did not affect rootability but may influence survival. Production of shoots on DKW with full strength $\mathrm{NH}_{4} \mathrm{NO}_{3}$ followed by induction for 6 to $8 \mathrm{~d}$ at $22^{\circ} \mathrm{C}$ on medium with at least $40 \mathrm{~g} \cdot \mathrm{L}^{-1}$ sucrose was optimum. Growth and elongation of apical buds during acclimatization was improved by application of $25 \mathrm{~mL} \cdot \mathrm{L}^{-1}$ Promalin.

\section{Literature Cited}

Bourrain, L. and J.C. Navatel. 1994. Micropropagation du noyer, Juglans regia L. Première partie: Production in vitro. Infos-Ctifl 98:40-48.

Bourrain, L. and J.C. Navatel. 1995. Micropropagation du noyer Juglans regia L. Deuxieme partie: Acclimatation en serre et élevage du plant en pépinière. Infos-Ctifl 112:28-33.

Chenevard, D., C. Jay-Allemand, M. Gendraud, and J.S. Frossard. 1995. Development of the photosynthetic ability of hybrid walnut plantlets during acclimatization. Ann. Sci. For. 52:147-156.

Driver, J.A. and A.H. Kuniyuki. 1984. In vitro propagation of Paradox walnut rootstock. HortScience 19:507-509.

Driver, J.A. and G.R.L. Suttle. 1987. Nursery handling of propagules, p. 320-335. In: J.M. Bonga and D.J. Durzan (eds.). Cell and tissue culture in forestry, Vol. 2. Martinus Nijhoff, The Netherlands.

Hackett, W., J. McKenna, T. Burchell, and C. Leslie. 2000. Stockplant manipulation to enhance rooting and nursery survival of walnut cuttings. Walnut Res. Rpt. 109-114.

Hasey, J.K., B.B. Westerdahl, W.C. Micke, D.E. Ramos, and J.T. Yeager. 2001. Yield performance of own-rooted 'Chandler' walnut versus 'Chandler' walnut on Paradox rootstock. Acta Hort. 544:489-493.

Hendricks, L.C., W.W. Coates, R.B. Elkins, and G.H. McGranahan. 1998. Selection of varieties, p. 84-89. In: D.E. Ramos (ed.). Walnut production manual. Univ. of California. DANR. C.A.

Jay-Allemand, C., P. Capelli, and D. Cornu. 1992. Root development of in vitro hybrid walnut microcuttings in a vermiculite-containing gelrite medium. Scientia Hort. 15:335-342.

López, J.M. 2001. Field behavior of self-rooted walnut trees of different cultivars produced by tissue culture and planted in Murcia (Spain). Acta Hort. 544:543-546.

McGranahan, G.H., C. Leslie, and J. Driver. 1988. In vitro propagation of mature Persian walnut cultivars. HortScience 23:220.

McGranahan, G.H., J.A. Driver, and W. Tulecke. 1987. Tissue culture of Juglans, p. 261-271. In:J.M. Bonga and D.J. Durzan (eds.). Cell and Tissue Culture in Forestry, Vol. 3. Martinus Nijhoff, The Netherlands.

McGranahan, G.H., D.G. Voyiatzis, P.B. Catlin, and V.S. Polito. (1994). High pollen loads can cause pistillate flower abscission in walnut. J. Amer. Soc. Hort. Sci. 119(3):505-509.

McKenna, J.R. 1997. Clonal propagation of Paradox walnut rootstocks by conventional methods. MS Thesis, Univ. of California, Davis.

Mircetich, S.M. and A. Rowhani. 1984. The relationship of cherry leaf roll virus and blackline disease of English walnut trees. Phytopathology 74:423-428.

Murashige, T. and F. Skoog. 1962. Arevised medium for rapid growth and bioassays with tobacco tissue cultures. Physiol. Plant 15:473-497.

Navatel, J.C. and L. Bourrain. 2001. Plant production of walnut Juglans regia L. by in vitro multiplication. Acta Hort. 544:465-471.

Pierik, R.L.M. 1997. In vitro culture of higher plants. Kluwer Acad. Publ., The Netherlands

Ripetti, V., C.L. Kevers, and T. Gaspar. 1994. Two successive media for the rooting of walnut shoots in vitro. Changes in peroxidases activity and in ethylene production. Adv. Hort. Sci. 8:29-32.

Saadat, Y.A. and M.J. Hennerty. 2001. The effect of different in vitro and ex vitro treatments on the rooting performance of Persian walnut (Juglans regia L.) microshoots. Acta Hort. 544:473 480 .

Scaltsoyiannes, A., P. Tsoulpha, K.P. Panetsos, and D. Moulalis. 1997. Effect of genotype on micropropagation of walnut trees (Juglans regia). Silvae Genetica 46:326-332.

Vahdati, K., C. Leslie, and G. McGranahan. 2001. Successful in-vitro rooting of mature walnut Hortscience 36:523.

Zamani, Z. and K. Vahdati. 2001. Influence of carbohydrate form and nitrogen source on growth of Persian walnut shoots in vitro. Acta Hort. 544:537-541. 